\title{
COOKING WITH REFUGEES AND MIGRANTS. STAGING AUTHENTICITY AND TRADITIONALITY FOR WARSAW'S CULINARY TOURISTS
}

\author{
MAGDA BODZAN \\ INSTITUTE OF ETHNOLOGY AND CULTURAL ANTHROPOLOGY, \\ THE UNIVERSITY OF WARSAW
}

\begin{abstract}
During the migration crisis of 20I5, a commonly shared belief about the integrating role of food resulted in the emergence of several culinary initiatives directed at refugees and migrants in Warsaw. I show that these culinary initiatives form a space for the creation of ostensibly opposing processes. On the one hand, they empower refugees and migrants by embracing the culinary cultures of their home countries; on the other, they facilitate the creation of simplified and folkloristic images of them. During culinary workshops, the role of migrants and refugees is to recreate traditional dishes, using "authentic" recipes. At the same time, they are restricted by the organizers' ethical foodways and the demands of Warsaw's culinary tourists, such as vegetarianism, to which migrants and refugees skilfully adapt. These processes result from a neoliberal logic, whereby refugees' and migrants' experiences and their ethnicity become commodities in the NGO market.

This article draws on ethnographic research conducted between 2017 and 2018 in Warsaw. I look at the biographies of six women refugees cooperating with selected initiatives. I analyse their strategies of recreating traditionality in the dishes they cook in order to authenticate their migration stories. I also examine their experiences and practices in the context of "food capital" that emerges as a result of the exchange of cultural capital between migrants and residents, and "refugee capital", defined as the ability to use refugee status for personal development and integration. Combining "food capital" with "refugee capital" turns out to be an excellent recipe for success for refugees' migration projects.
\end{abstract}

KEYWORDS: food capital, refugee capital, cooking, refugees, authenticity, culinary tourism, gender

In 2015 Europe recorded an unprecedented number of asylum seekers and refugees trying to enter its borders. This was also the year of parliamentary and presidential elections in Poland, which were won by the Law and Justice party and its representative for the post of president. The party had fuelled anti-migrant and anti-refugee discourse already in its election campaign; on coming into office, it ruled against receiving any number of refugees in Poland and has continued such policies ever since (Buchowski 2016). According to the "Contempt Speech, Hate Speech" Report (Bilewicz et al. 20I7), in 2016 refugees, along with gay people, were the most common victims of hate 
speech in Poland (Bilewicz 2016, 5). Fear mongering and anti-refugee discourse were repeatedly mentioned in the interviews I conducted with migrants and refugees in Warsaw in 20I7-20I8. They described experiencing intensified verbal and physical attacks on their communities at that time.

This anti-refugee discourse was opposed by those who were critical of the new government's policies. The availability of additional foreign funds for projects directed at refugee integration resulted in a rise in the number of entities interested in doing them. These projects were proposed by social enterprises (Kuchnia Konfliktu), socially engaged cafeterias (Stót Powszechny, Zieleniak), NGOs and informal groups (TAK dla uchodźców), some of which had no prior experience of working with refugees. They joined a field in which there existed already functioning and recognized organizations and initiatives offering various forms of help for refugees and migrants. However, their emergence also strengthened existing tensions in the Third Sector: rivalry in accessing grants and the fact that donors often preferred innovation over experience.

Numerous of these NGOs and informal groups organized all kinds of workshops and meetings during which cooking with refugees and migrants constituted a means to combat fear and negative attitudes towards newcomers. The projects aimed at creating a space for multicultural dialogue and at generating income for their beneficiaries. Migrants and refugees were given the task of preparing traditional dishes according to authentic recipes. The very act of cooking was supposed to put migrants and refugees in the role of agents, in order to help them leave the subordinate role manifested in their everyday difficulties in getting access to the job market and housing. For the inhabitants of Warsaw, culinary workshops were supposed to be a space where they can meet Others and learn about their culture in an accessible way.

How do refugees and migrants recreate original dishes and authentic recipes during such workshops? How do they adapt them to the organizers' ethical foodways and Warsaw's culinary tourists' demands, such as vegetarianism? How do they obtain food capital and refugee capital? What do they use it for? Based on the results of ethnographic research conducted between 2017 and 2018 in Warsaw', this text aims to answer the above-mentioned questions by analysing practices and narratives concerning the involvement of six refugee women in culinary activities.

During the course of the research, I conducted 20 in-depth interviews with migrants, refugees and the organizers of five cooking initiatives: Kuchnia Konfliktu (Conflict Kitchen), GośćInność, (Hospitality) Historie Kuchenne (Kitchen Stories), Kisz

I The research was conducted as part of the ethnographic laboratory group "Migrants and refugees domesticating space. Anthropology of mobility in Warsaw and its vicinity" (2017-2019) led by Karolina Bielenin-Lenczowska and Helena Patzer at the Institute of Ethnology and Cultural Anthropology, University of Warsaw. 
Misz (Kish Mish) and Kuchnia Migrujaca (Migrating Kitchen). ${ }^{2}$ I also talked to two participants of the workshops. The interviewees were from Afghanistan, Algeria, Belarus, Chechnya, Ukraine, Georgia, Kyrgyzstan, Syria, Tajikistan, Tibet, and Ukraine, while the organizers and participants were all Polish. I did participant observation in I2 culinary events organized by three existing culinary initiatives. The events took place in schools (2), public parks (4), a private house (I) and cultural centres, as part of the celebrations of World Refugee Day (4) and as Multicultural Breakfasts (I). For eight years (2010-20I8), I have worked for multiple NGOs in the field of global education, humanitarian aid and advocacy for food sovereignty, thus I was very familiar with the conditions in which the Third Sector operates in Warsaw and I well understood the systemic limitations of the initiatives.

2 Kuchnia Konfliktu was created in 2015 as a space for dialogue and integration, giving refugees and migrants in Poland jobs and a chance to share the cuisine of their regions. The aim of the project is to intervene in public spaces through cooking. Thanks to Conflict Kitchen, Warsaw inhabitants have an opportunity to learn about the cultures of countries affected by armed conflicts and interact directly with the refugees and migrants who contributed to the project. The restaurant was closed in July 2020 as a result of the COVID-I9 pandemic and at present serves takeaway meals. The founders of the initiative are Jarmiła Rybicka, Paulina Milewska and Maciej Kuziemski. This information comes from the Conflict Kitchen's Facebook page and has been translated by the author. https:// www.facebook.com/kuchniakonfliktu/ (accessed 09.II.2020).

Gośćlnność (the direct meaning is hospitality, but it is also a word play of two words: gość - guest, inność - difference) is an educational project funded by Nina Łazarczyk-Bilal, directed primarily at schools and young people. Under the guidance of migrant/refugee cooks, students prepare dishes from the cook's country of origin. They learn about the causes of migration and who migrants and refugees are. https://www.facebook.com/DobraStronaSwiata/ (accessed 09.II.2020)

Kisz Misz was a cooperative whose main goal was to create jobs for excluded people, including forced migrants. The initiative did not have its own kitchen. The formula of cooperation was variable - at one stage it provided catering, and in the summer the initiative had a stand on the banks of the Vistula. It was set up by the social cooperative "Terra" in 2013 and was closed in 2015. http://www.smakizycia.pl/wydarzenia/polecamy/kisz-misz-przez-kuchnie-do-zrozumienia/ (accessed 09.1I.2020).

Historie kuchenne is part of a bigger project called CzujCzuj (Feel Feel), an initiative in the field of emotional education founded by Olga Ślepowrońska in 20I0. The project is addressed to all excluded groups, including people with disabilities, Roma people and refugees. In 20I2, Olga came up with KITCHEN HISTORIES, an interdisciplinary project based on the cultural heritage of representatives of various nationalities and ethnic groups living in Warsaw (not only refugees). https:/www.facebook.com/histokuch/ (accessed 09.II.2020).

Kuchnia Migrujaca was a catering company opened in 2015, in which refugees cooked for bigger events and business companies. They specialized in larger orders for 80-IOO people. For its organizer, Alicja Pękalska, who was formerly involved in the Kisz Misz cooperative, the most important aspect of her business was financial support for refugees and migrants, and the creation of an efficient business. It ceased existing in 2019 . 
I decided to choose women refugees as research subjects because of their central role in foodways and culinary cultures. As Arlene V. Avakian notes, "Cooking is something that was and continues to be imposed on women" (1997, 6). The analysis presented here applies the concept of food voice, which understands food as a channel for the expression of meaning (Hauck-Lawson 20I5, 2I), as one of the possibilities to conceptualize the power and agency that women gain by cooking (Belasco 2008, 44). What the article adds to the existing body of knowledge is an analysis of the ways in which female refugees use their refugee and food capital for their own development and wellbeing. By examining refugees' deliberate practices of performing authenticity and traditionality of food in their host country, this analysis expands the study of food and migration through the topics of the commodification of refugee experience and of the agency of female refugee cooks.

\section{FOOD AND MIGRATION}

Most studies of food and migration have concentrated on the relationship between migrants and host societies, and the processes of integration and acculturation. They touch upon issues such as migrant agency, the (re)creation of home culture through food (Avakian 1997), the construction of culinary culture (Ray 2004; Mlekuz 2017), ethnicity and the concepts of belonging (Cook et al 1999; Diner 200I; Williams-Forson 2006) and gustatory boundaries in relation to "others" (Ray 2004). Since migrants are placed in a state of flux, they are subject to a range of influences in their everyday lives which construct and reconstruct their identities (Vallianatos and Raine 2008; Brembeck 20I4; Abbots 2016). Food, being an element of the wider social setting, can facilitate the creation of new subjectivities. It embodies not only the place of origin, but also the achievements of migrants in their host societies (Diner 200I). Through smells and tastes, food can transport migrants back home (Seremetakis 1994 Stoller 1989; Sutton 200I; Ben Ze'ev 2004). In the words of a Palestinian chef, Sufian al-Ahmadi, it is because food is more than its delicious flavour: it is "the atmosphere, aroma, the taste, the memory (...) the family and above all, home” (Ben Ze'ev 2004, I52). For the very same reasons, food plays an active role in anchoring migrants in their new locations.

Food is also embedded in a set of relations of power and domination and can provide insights into the complex life of a migrant. Thus, food can be a powerful lens for understanding forms of exclusion and inclusion in host societies. This particularly relates to refugees in refugee camps and centres, whose food sovereignty is challenged by the fact that for months (or years) they are dependent on food provided by foreign governments, international agencies, NGOs and informal help groups. The food that is provided as part of such assistance reveals a lot about host countries' attitudes towards newcomers and is an issue regularly raised by refugees (Trapp 2016; Dunlop 2017). 
Elizabeth Dunn, who spent a year doing research in a refugee camp in Georgia, called food aid products, such as macaroni, a symbol of the nothingness of displacement, food made by nobody and given out by nobody, the antithesis of deeply place-linked food (Dunn 20I2, 40). This is because the nutritional logic embedded in humanitarian aid intends to provide enough calories per day per person, but not to ensure essential nutrients or culturally appropriate flavours. Refugees are expected to adapt to the most economical foods (Trapp 2016). The refugees I interviewed mentioned having been served stale food soaked in vinegar (to mask the bad taste) in the refugee centres they had lived in Poland.

Helen Brembeck who studied Bosnian women refugees in Sweden has also noted that for her interviewees eating and cooking formed a way to survive, not only physically, but also socially and culturally, during long months in refugee camps. Preparing meals filled their days with content and meaning and well-known roles and identities, creating a sense of normality in a chaotic world. It was a way to keep the family in check and adapt to the new homeland (Brembeck 20I4, I06). For Chechen women refugees in Poland studied by Katarzyna Kość-Ryzko, cooking typical dishes from the home country despite limited access to many products was essential in raising their children so that "they do not forget their culture", "know where they come from" and "know their flavours". As she notes, this was not a result of a veiled ethnocentrism or reluctance to integrate. Rather, it came from a belief that they were the only pillars figuratively - supporting their homes (without other fundamental "supports" in the form of a father, relatives or members of the community) and their exclusive role as "cultural reproducers" (Kość-Ryżko 2019, 265-267).

\section{FOOD CAPITAL}

Some researchers have shown that during the first phase of migration, refugees and migrants often suffer from food deprivation, either physiological, in the form of malnourishment, or socio-cultural, in the form of limitations of food autonomy and food preferences (Tolstokorova 2018, 82; Terragni et al 20I4, 278). Drawing from Bourdieu's theory of non-monetary capital, Tolstokorova uses the notion of "food capital", which I find useful for the analysis in this article. She understands food capital as resulting from the exchange of "cultural capitals" between locals and migrants which endows to the latter "food dividends of migration". In other words, food capital accrues through an embodiment of new food --related experiences enabled by access to foreign food cultures through migrancy. It also includes "culinary and gastronomic dividends", understood as learning the new skills and ways of cooking characteristic of the host cultures (Tolstokorova 2018, 72). Food capital is used by migrants for their own personal development and wellbeing, and together with the food dividends of migration, 
is tied to place, i.e. the locale where it is invested - in the recipient society or at home (Tolstokorova 20I8, 82).

Five out of the six women refugees I take as the key cases for this study acquired food capital in refugee centres, where they spent their first months or years after arriving in Poland. It is in the centres where their first encounter with Polish cuisine occurred. Through receiving strictly local food cooked by Polish cooks in the centres' canteens, my interlocutors got to know the "basic foods" and the primary edibles of the host country (Belasco 2008, I6). All my interlocutors also participated in culinary courses organized by various NGOs on the premises of the refugee centres. They thought of cooking as a potential paid job which non-native Polish speakers can take, even if some of the women I interviewed did not enjoy it and saw it more as a household duty, eagerly delegated to other family members or to home help in their country of origin. One of them recalled the words of her father who used to say that: "There are two things people could not do without: food and clothes". Acquiring knowledge of food products available in Poland was also important for their survival. The food they received in the centres was not sufficient for all their family members and they were forced to cook additional meals. As one of my interlocutors said, she became "the queen of the kitchen for Io PLN", as this was the amount of money she had each day for additional food for her entire family.

During the culinary courses organized by NGOs, my interlocutors not only learned new skills, products and taste preferences of Poles, but also saw that there is a demand for refugees cooking traditional dishes from their countries of origin on the market of Polish non-governmental organisations. NGOs that carry out projects directed at refugee integration organize various events outside refugee centres during which Poles can get to know refugees, and cooking together is one of the integrative activities they propose. Thus, it is important for NGOs to have direct relationships with refugees as it increases the attractiveness of their grant applications and their chances of receiving funds. My interlocutors recognized this opportunity, and to expand their food capital would call family members who had remained back home for recipes of local dishes.

Women refugees who enjoyed cooking and acquired food capital through exposure to Polish food in the refugee centres and through cooking courses offered by NGOs eagerly made use of it outside the centres. Conversations with them were enriched by talks about recipes, and differences and similarities between Polish cuisine and that of their home countries. They also told me numerous anecdotes about what they managed to arrange for themselves or their families thanks to cooking and to offering dishes from their home countries which were suitable for the local palate. One of my interlocutors offered a falafel sandwich to a woman who had repaired her TV. Not only did she not pay for the repair, but she also gained a new friend with whom she

3 Io PLN is about 2,5 EUR. 
regularly goes to an allotment garden near Warsaw. Women who have children in Polish schools often talked about preparing dishes for multicultural days or other school events. They said their dishes pleased many people, and their cooking skills and sense of culinary taste paved the way for the faster integration and acceptance of their children in schools (cf: Terragni et al 20I4). My Chechen interlocutor used her private money received from the Office for Foreigners to cook for her Polish neighbours when she moved into a new place. She set up a stall in the nearby park where she offered mantas and chepalgash for free. When asked why she used her private money for this, she replied that: "This was the price for integration; otherwise people wouldn't know us". These stories show that my interlocutors consciously used their food capital to build social capital and integrate themselves in the host society.

\section{FOOD PERFORMATIVITY:}

\section{AUTHENTICITY, TRADITIONALITY AND CULINARY TOURISM}

Refugees and migrants involved in the culinary workshops I observed mostly came from war-torn places that are difficult to travel to, such as Afghanistan and Syria, or places that are interesting for Poles in terms of tourism, such as Kyrgyzstan, Tajikistan and Georgia. During the workshops, questions circled mostly around food (ingredients, differences and similarities between cuisines) and tourism (recommendations of tourist attractions). Cooking refugees and migrants were presented as representatives of a distant culture, an exotic "Other". As the American folklorist Lucy Long notes, one of the dimensions of distinguishing otherness is that of an ethnic and national identity of which foodways are a constituent part (Long 2004, 24). Thus, participation in workshops where migrants and refugees cook can be perceived as an example of culinary tourism, which she describes as "the intentional, exploratory participation in the foodways of an other - participation including the consumption, preparation, and presentation of a food item, cuisine, meal system, or eating style considered to belong to a culinary system not one's own" (Long 2004, 2I).

By dint of the intentional exploration of new foods, the audiences of the workshops, no matter whether they be new middle-class consumers, NGO workers or schoolteachers, become culinary tourists using food to explore new cultures and ways of being. One workshop participant I interviewed admitted that her reason to join was because she had never tasted Chechen food. A tourism based motivation of participants was also visible to my refugee interlocutor. She noted that people have more interest in workshops on Georgian than on Chechen food. The explanation she gave was that: "Poles can go to Georgia sooner than to Chechnya, and they want to know more about Georgian cuisine. It is not known when they will be able to go to Chechnya, and Georgia is easily accessible." 
However, it is important to note that culinary tourism is based on a dialogue between producers/presenters of food and individuals who are exploring foods that are new to them. In the case of culinary initiatives involving refugees and migrants, the power structures are different since the initiative organizers are intermediaries between the producers and their clientele. They limit refugees and migrants' decisions about the choice of dishes and ingredients by imposing the requirements of authenticity and traditionality of dishes, and understanding authenticity as an objective category (MacCannell 1973) and a moral ideal (Bornstein 1973).

Arjun Appadurai argues that authenticity means the degree to which something should be a norm. He wonders who can really create this in culinary terms - a professional cook, an ordinary consumer or maybe a housewife (Appadurai 1986, 25). In the logic of the initiatives I was studying, authenticity is ensured by the ethnicity of the cook. This is well illustrated by the content of advertisements of cooking workshops:

Family cooking workshops will be conducted by Elmira from Kyrgyzstan. Together with Elmira, we will learn the history of her country's culinary traditions, fry pancakes (boorsoki) and vegetable funchoza together. ${ }^{4}$

Syrian cuisine workshops with the Ocalenie Foundation and Karima who will talk about what a traditional Syrian meal looks like (...). Karima is a cultural educator. She has Polish-Syrian roots, and was born and raised in the Syrian city of Aleppo. ${ }^{5}$

Thus, "staging authenticity" is a common practice at the workshops. Dean MacCannell, who coined this term, derived it from Erving Goffman's study of social performance and the division of the social world into back and front regions: "The front is the meeting place of hosts and guests (...) and the back is the place where the members of the home team retire between performances to relax and to prepare" (MacCannell I973, 92). A tourist, wanting to experience authenticity, wants to go to the back regions, but most often becomes a viewer of a precisely directed spectacle. MacCanell claims that the tourist will always be entangled in a paradox: something that $s /$ he considers authentic is only the authenticity created for her/his needs.

Migrants and refugees, being cultural brokers, are supposed to guarantee admission to the back regions to workshop participants. Some refugees took this requirement seriously. As one of them said:

4 https://grodzisk.pl/wydarzenie/tradycyjne-kuchnia-kirgiska-warsztaty-rodzinne/ (accessed o9.II.2020). It is interesting in this context that funchoza is an "acquired dish" in Kyrgyz cuisine, probably adopted from Uighur or Korean cuisine. It is a popular dish in the whole region of Central Asia, but it is not traditionally Kyrgyz. It contains too many vegetables to be authentic Kyrgyz, since flour, dairy products and meat are the basic ingredients in Kyrgyz cuisine. I would like to thank one of the reviewers for pointing this out.

5 https://www.facebook.com/events/55028579543508I/ (accessed 09.II.2020). 
Well, I really tried to make it authentic, but it was a bit different from real Georgian food, because it wasn't possible to do it there. For example, eggplant with nuts must be made in a blender with porridge, very soft porridge. The walnut sauce looks completely different then. But we didn't have blender and we couldn't do it.

Some brought their own spices or recipes written in their own languages. However, there were also refugees who played with convention, as in this example: "Sometimes at the workshops I was making cookies. It was my recipe, but I was saying it was traditional Kyrgyz."

The refugees made conscious use of their position as the exotic "Other", as well as of their food capital, to respond to the needs of Warsaw's culinary tourists imposed by the organizers. Staging authenticity and performing traditionality were strengthened by additional elements, such as putting on traditional clothes for the workshops, performing traditional songs and dances, and performing practices which are associated with a given country, such as fortune-telling from coffee grounds.

M: And how did you learn fortune-telling from coffee grounds?

$\mathrm{K}$ : From the internet, now everything is there! I mean, earlier, when we were sitting with my female neighbours, each of us tried to do it. I heard that snake means something, bird means something else. And the rest I took from the Internet. I found a list, learned it a little, but also printed it for the workshops. And then you look, think what is drawn there, and you interpret it somehow.

My interlocutors learned fast that their ethnicity makes dishes and crafts appear authentic and that the words "authentic" and "traditional" are key in attracting an audience to such multicultural meetings, as the example below shows: "I showed them some slides and explained the meaning of felt in our culture. I prepared something fake out of it, but said it was traditional Kyrgyz. Well, of course it was not, but people liked it and now I already have several people coming to my classes."

Staging authenticity is a survival strategy for my interlocutors. They have been performing stories and images of themselves and their countries of origin from the very beginning of their journey, especially at the Polish border. They often compared this experience to being in a theatre, in which every person or institution had a role to play. There was a shared set of conventions - about what should be said and which actions were inappropriate - knowledge of which guaranteed the favour or disapproval of border guards, the defenders of the security of the Polish state. Culinary workshops were just another dimension of the same authenticating spectacle, inscribed in the culinary tourism frame of "groups using food to 'sell' their histories and to construct (...) publicly attractive identities" (Long 2004, 20).

Thus, stories about countries of origin and reasons for migrating are a particularly important part of the workshops. They are included in workshop advertisements and 
usually also include short bios of the refugees who cook, and the skills and talents they possess. This is done to deanonymize individuals and show their non-refugee/ migrant identities. Refugees are also expected to tell stories during the workshops. Most often, they consist of descriptions of nature, interesting places to see and tasty dishes to eat in their homeland. The approach of initiative organizers differs with regard to how much refugees' stories should be revealed. Some initiative organizers build their narration around them in order to show how much refugees have been through. Others see this as a desire to feed on someone else's emotions. As one of the organizers explains:

You have something you have seen on TV, that is so awesome that you want to listen to and experience it. It's like a hunger for revelations, without realizing that this is someone's life. These people sometimes been through strong traumas, and maybe they just don't want to talk about it.

However, I observed that workshop audiences tend to expect detailed stories explaining why people needed to leave their homes. In other words, my interlocutors are expected not only to stage the authenticity of their dishes, but also of their migration stories: they need, as it were, to authenticate their presence. And in the same way as they invent dishes to fit the needs of Warsaw culinary tourists, they also invent their migration stories, as was pointed out to me by one of the initiative organizers:

They [Polish clients] ask: "In Africa, how did you prepare those dishes? How do you season them?' Often, they don"t season them at all, because there is nothing to eat for example, or you eat the same thing all the time, and you do not care, whether you add more nutmeg or sweet pepper, because you do not think in such categories. Or "What did you do professionally when you lived in Congo? Probably nothing, right?" And then, you know, they invent stories. "Well, I've been doing this and that there for so many years."

Appadurai concludes that the notion of "authenticity" should not be applied to culinary systems at all, since it ignores the historical process of their evolution and implies an objective reality. Many argue that authenticity is negotiable and socially constructed (Molz 2004, 56). It is not about whether someone experiences authenticity, but what makes a given experience seem authentic. What I learned from my interviews with initiative organizers was that the reason why they decide to adopt MacCannell's definition of authenticity is the attractiveness of the promise of getting their audiences to the back regions. However, I argue that such an approach results in ethnicization and refugee and migrant experiences being seen as objects of experience rather than as lived by experiential subjects.

Such an approach also inscribes initiatives into a cosmo-multicultural discourse that requires little to no engagement between migrants and hosts. It positions the "ethnic feeders" as passive objects and gives subjectivity to cosmopolitan eating subjects (Hage 1997, 17). Ghassan Hage calls it a multiculturality without migrants, a plurality 
of cultures without a plurality of people from different cultures, where otherness is perceived as a commodity, as abstract ethnic value, in other words as a product of forces which are far more linked to tourism and the international circulation of commodities than to the circulation of migrants (Hage 1997, 18).

The commodification of cultural products and practices, which John and Jean Comaroff accurately called "Ethnicity, Inc.", is a common commercial practice of ethnic cuisines. What I observed during workshops is that socially constructed notions of culture and authenticity, instead of being subject to criticism, are rather reinforced. The emphasis is placed on the interaction between "cultures", on tolerance and positive aspects of cultural diversity, which are limited to their most superficial and folkloric manifestations. Thus, celebrations of multicultural foods in the form of "cooking with refugees and migrants" workshops may deflect attention away from the structural inequalities that migrants and refugees face each day, such as very limited access to the job market and to housing. The staging of actively (re)constructed authenticity by migrants and refugees, as presented above, is a consciously applied survival strategy on their part.

\section{VEGETARIANISM AND ETHICAL FOODWAYS}

The requirement of authenticity and traditionality of dishes does not mean they are not subject to modifications. Vegetarianism or the ethical origin of products is often a must, even if this means creating new, hybrid dishes, not known in the home countries. These are conditions often imposed by the organizers of culinary initiatives, not proposed by the migrants and refugees themselves. The vegetarian restriction results from several factors. One aspect is that of sanitary requirements and logistical considerations. This is particularly important for initiatives that do not have their own kitchen and organize workshops in schools or community centres. As one of my interviewees explained:

I proposed to the girls a recipe in two versions, a meat and vegetarian one. I think we did the vegetarian version because of simplicity. You must get to the school, the meat must be fresh, and so on. Later they said we needed to make two versions, because there might be kids on a vegetarian diet, and we would have to give them something. Making two versions complicated things, so logistically it was easier for us and nobody complained after the event.

Another factor is the growing demand for vegetarian dishes from clients. Plant-based cuisine has become immensely popular and even fashionable in Warsaw, as evidenced by the growing number of vegan and vegetarian eateries. ${ }^{6}$ Migrants and

6 https://www.happycow.net/vegtopics/travel/top-vegan-friendly-cities (accessed 09.II.2020). 
refugees who have been living in Poland for several years have observed this trend themselves, stressing that the tastes of urban Poles are changing. One initiative organizer recalled several orders, including one from a town hall and another from a large corporation, where strictly vegan and vegetarian meals were desired. This might reflect the specificity of the clients my interviewees cater to, who are well-travelled, cosmopolitan Warsaw foodies. However, in some circles, especially those related to the Third Sector, as I know from my own experience, a vegetarian menu is expected to be offered by such enterprises as a sign of inclusiveness, a concern for the environment and integrity.

The personal beliefs of organizers are another important factor. All initiatives are run by well-educated and well-travelled women, who are aware of the social and environmental impacts of meat production. Since their main goal is to keep their initiatives running in order to secure a stable workplace for migrants and refugees, they must take the above-mentioned factors into account.

Vegetarianism is therefore a principle to which migrants and refugees cooperating with culinary initiatives must adapt and modify their recipes accordingly, sometimes completely changing the original dish, as in this example: "Vereshchaka is a thick sauce, which is authentically cooked from various types of meat or sausages, with a little roux. But I modified it and we did a vegetarian version, with celery. In fact, only vegetables were there."

For some migrants and refugees, vegetarian modifications of dishes do not pose a problem. They underline economic savings, the health benefits of including more vegetables in their dishes and that there is less hassle with preparation. Some introduce vegetarian dishes in response to their clients' needs or perceptions about the countries they represent. My Tibetan interlocutor included lentil dumplings in the offer, while admitting that typically they are served with yak meat. Vegetarianism has only recently become Tibet's youngest "invented tradition" in exile (Bloch 20IO) in order to fit with Western ideas about Tibet. Western logic has connected the Buddhist compassion for "all sentient beings" with not eating meat, and nowadays this image is used by Tibetan elites to promote their cause internationally (Bloch 20IO, I24).

For my Chechen interlocutors, replacing meat with some other ingredient is perceived as a form of aberration:

K: We do not make vegetarian mantas at home, for ourselves, because we make them with meat.

They taste better. They should be with meat.

M: In Chechnya you don't eat meatless mantas at all?

K: No, we do not eat them.

M: They are always with meat?

K: Yes. They are always with meat.

M: Oh, I thought there could be meat or vegetarian ones.

K: No. 
For them, meatless dishes have a different symbolic "weight" than dishes with meat (Belasco 2008, 34). They are lower-valued and perceived as poor people's food. Vegetarian dishes are mostly eaten when there is no money for meat and thus they are not dishes served to guests. Meatless meals do not fit into the category of "proper cooking" which involves more effort and a greater use of foods that the cook considers more unusual and special (Short 2006, 28). While leading their cooking workshops, the Chechen women repeatedly stressed that traditionally mantas are prepared with meat, and the reason we cooked them with spinach and cheese was just for the sake of the workshops. Thus, they were asked to cook dishes representing the richness of their regional cuisine, which they themselves did not find representative enough in their vegetarian version. One of the organizers told me that her Chechen employees were always talking about mantas with beef, and only when they were forced to come up with vegetarian dishes did they mention mantas with nettle or pumpkin pie. What Chechen women were referring to were probably the categories of food for guests and proper festive meals as the accurate representation of their food culture, while the organizer was asking them to prepare everyday dishes which do not fit the idea of good hosting. However, as creative women in need of employment, they adapted to these constraints with ease.

Another requirement coming from the initiative organizers is that of the ethical origin of the products used in cooking, i.e. the use of Fair Trade or ecological products, or "ugly" vegetables coming from dumpster dives in the spirit of so-called ethical consumption. From the organizers' point of view, the use of such products has a deep sense, as it shows the initiatives' integrity: an important keyword in the discourse of NGOs. By using Fair Trade products, they support not only migrants and refugees in Poland, but also small-scale farmers in the global South. By using ecological or "ugly" vegetables, they have less negative impact on the environment.

Introducing vegetarian restrictions and/or the usage of ethical ingredients can be interpreted as imposing not only ethical foodways understood as moral practices related to the production and consumption of food (Goody 1982, 157) but also the classist and ethnocentric attitude of the urban middle class towards the migrants and refugees involved in the initiatives. Whenever the migrant cooks mentioned products such as palm oil or Maggi sauce, which are normal ingredients in their home countries, it always aroused whispers of disgust among participants, who considered them unethical.

In 20II, when I was coordinating a project that promoted the idea of Fair Trade, such products were not available in most cities and towns in Poland and were chosen mostly just by followers of ethical consumption (Kuszkowska 20I2, 27). Nowadays, vegetarianism, veganism and ethical consumption form part of the fashion for sustainability ${ }^{7}$ and are one of the main proposals of the climate movement. Adaptation

7 https://home.kpmg/xx/en/home/insights/20I9/oI/trend-6-sustainability-goes-mainstream.html (accessed 09.II.2020). 
of food recipes to exclude meat and unethical products also show migrants and refugees as agents who skilfully navigate in this imposed ethical consumer paradise.

\section{CONCLUSIONS}

From the perspective of my interlocutors, cooking with refugees and migrants is a good way to integrate into Polish society. When asked whether it had changed anything in their lives, one of the women replied: "Were it not for food, I would not have been in the place I am now." For her, it was not only an opportunity to earn money, but also to build social capital, and regain confidence and a sense of agency. Another believed that amongst the sweetest conversations one can have are those at the table, and enjoyed showing Poles her local food and being praised for its good taste. For a woman who held a public position in her home country, cooking satisfied her need to be the centre of attention. She also recalled workshops, after which a man who had declared holding prejudices against refugees changed his mind. The role of culinary initiatives is thus not limited to financial assistance for migrants and refugees, but also to social capital building and the potential to change attitudes in the host society. For these reasons, social initiatives directed at refugees and migrants choose activities centered around food and cooking together as a tool for integration.

However, I observed that the ways in which cooking with refugees and migrants workshops are organized fit into the assumptions of a cosmo-multicultural discourse (Hage 1997) linked to tourism and the circulation of culinary commodities and concepts, rather than the circulation of migrants. Such a discourse places migrants and refugees in an "us" and "them" dichotomy, and facilitates the creation of simplified folkloristic images of their countries of origin. Refugee and migrant experiences, together with ethnicity, become commodities in an NGO market where organizations compete for grants according to a neoliberal logic. Those refugees and migrants who have lived in Poland for some time now and move with great ease in the Third Sector use this as an opportunity to negotiate the pay for their work. They are aware that the uniqueness of their identities and a skilful reproduction of the authenticity and traditionality of their home dishes, combined with gracefully told stories about their refugee and migrant experiences are attractive commodities for the NGO market. However, as Hage notes: "To say that a specific kind of practice entertains certain illusions about itself and that it is based in a relation of power does not invalidate it, for such illusions are part and parcel of all cultural practices" (1997, 40).

Food plays a significant role in "anchoring" migrants in host societies and facilitates the creation of new subjectivities. Thus, it can be a great tool for challenging the dichotomous paradigm of "us" and "them". This could be done by assigning new meanings to it and taking a transnational perspective on the food-migration nexus. 
One could look at hybrid dishes created by migrants and refugees or examine migrant foodways and build a dialogue around these processes. Refugees and migrants also participate in the global circulation of culinary commodities and have their own food adventures. Asked about them, one of my Chechen interlocutors replied:

I just love Japanese cuisine very much, especially sushi. God, I wouldn't have survived without it, I'm really so caught up in it. I tried to prepare sushi myself and it turned out pretty good, but I prefer to go somewhere and eat it.

Such an approach would also relieve the burden of staging authenticity from migrants and refugees and transfer it to the culinary tourists experiencing it. In changing the way culinary initiatives perceive authenticity, the concept of "hot authenticity", coined by Tom Selwyn, might be particularly useful as it refers to the experience of the subject. Such "hot authenticity" arises from individual ideas about one's own life and a critical look at it, as well as from ideas about the reality that can appear during the journey. It emphasises the description of the subjective expectations and motivations of a tourist, including those related to cuisine (Horolets 20I2, II9). Last, but not least, migrants and refugees' consent to play an active role in this spectacle can be seen not only as a sign of their subordinate position and purely economic needs, but also as a practice through which they try to make themselves feel at home in Poland.

\section{REFERENCES}

Abbots, Emma-Jayne. 20I6. "Approaches to food and migration: rootedness, being and belonging." In The Handbook of Food and Anthropology, edited by Jacob A. Klein and James L. Watson, II5-I32, London: Bloomsbury.

Appadurai, Arjun. 1986. "On culinary authenticity." Anthropology Today 2: 25.

Avakian, Arlene V. 1997. Through the Kitchen Window: Women Writers Explore the Intimate Meanings of Food and Cooking. Boston: Beacon Press.

Ben Ze'ev, Efrat. 2004. "The politics of taste and smell. Palestinian rites of return." In The politics offood, edited by Marianne E. Lien and Brigitte Nerlich, I4I-I60, Berg Publishers.

Belasco, Warren. 2008. Food. The key concepts. Oxford and New York: Berg.

Bilewicz, Michał et al. 2017. Contempt Speech, Hate Speech. Report from Research on Verbal Violence Against Minority Groups. Centre for Research on Prejudice of the University of Warsaw; Io.13140/ RG.2.2.I4998.55366 (accessed 9.II.2020).

Bloch, Natalia 20ı0. "Czy jakożerca może zostać wegetarianinem? Globalny dyskurs praw zwierząt jako „tradycja wynaleziona” w diasporze tybetańskiej." Lud 94, I2I-I42.

Bloch, Natalia 20II. Urodzeni uchodźcy. Tożsamość pokolenia mtodych Tybetańczyków w Indiach. Wrocław: Monografie FNP, Seria Humanistyczna, Uniwersytet Wrocławski.

Brembeck, Helen. 20I4. "Food, cooking and motherhood amongst Bosnian refugees in Sweden." In Motherhood, Markets and Consumption. The Making of Mothers in Contemporary Western Culture, edited by Stephanie O’Donohoe et al., IO4-II5, Abingdon and New York: Routledge Interpretive Marketing Research (Book I8). 
Buchowski, Michał. 2016. "Making anthropology matter in the heyday of Islamophobia and the "Refugee Crisis': the case of Poland." Ceský lid: etnologický ćasopis I03 (I), 5I-67.

Cook, Ian, Crang, Philip and Thorpe, Mark. 1999. "Eating into Britishness: multicultural imaginaries and the identity politics of food." In Practising Identities: Power and Resistance, edited by Sasha Roseneil and Julie Seymour, 223-248, Basingstoke: Macmillan.

Cook, Ian, Crang, Philip and Thorpe, Mark. 2004. "Tropics of consumption: getting with the fetish of 'exotic' fruit?" In Geographies of Commodity Chains, edited by Suzanne Reimer and Alex Hughes, 173-192, London \& New York: Routledge.

Diner, Hasia R. 20or. Hungering for America. Italian, Irish and Jewish Foodways in the Age of Migration. Boston: Harvard University Press.

Dunn, Elizabeth C. 20I2. "A gift from the American People." The Iowa Review 42 (2), 37-48; doi.org/10.17077/002I-065X.7159 (accessed 9.II.2020).

Dunlop, John B. 2017. Exodus: St John Maximovitch Leads His Flock out of Shanghai. New York: Orthodox Profiles (Book 9), St Vladimirs Seminary Pr.

Hage, Ghassan. 1997. "At home in the entrails of the west: multiculturalism, 'ethnic food' and migrant home-building." In Home/World: Communality, Identity and Marginality in Sydney's West, edited by Helen Grace et al., Sydney: Pluto Press.

Hauck-Lawson, Annie. 20I5. "When food is the voice: a case study of a Polish-American woman." Journal for the Study of Food and Society, 2 (I), 2I-28.

Horolets, Anna. 20I2. Codzienność jako atrakcja turystyczna w doświadczeniu turystów niszowych do byłego ZSSR. Kultura i spoteczeństwo, 3, II3-I30; https://doi.org/I0.2478/viO276-0I2-0026-O (accessed 9.II.2O2O).

Kuszkowska, Anna. 20I2. "Fair Trade bez usprawiedliwień." (op.cit.) 43, 24-28.

Long, Lucy M. 2004. "Culinary tourism: a folkloric perspective on eating and otherness." In Culinary Tourism, edited by Lucy M. Long, 20-52, Lexington: The University Press of Kentucky.

MacCannell, Dean. 1976. A New Theory of the Leisure Class. Berkeley and Los Angeles: University of California Press.

Mlekuz, Jan. 2017. "We asked for workers. We got bureks instead. Meanings and material significance of the Burek in Slovenia." Ethnologia Europaea 47 (2), 72-86.

Molz, Jennie, G. 2004. "Tasting an imagined Thailand: authenticity and culinary tourism in Thai restaurants." In Culinary Tourism, edited by Lucy M. Long, 53-75, Lexington: The University Press of Kentucky.

Ray, Krishnendu. 2004. The Migrant's Table: Meals and Memories in Bengali-American Households. Philadelphia: University of Pennsylvania Press.

Seremetakis, Nadia (ed.). 1994. The Senses Still: Perception and Memory as Material Culture in Modernity. Boulder CO: Westview.

Short, Frances. 2006. Kitchen Secrets. The Meaning of Cooking in Everyday Life. Oxford: Berg.

Sutton, David. 200I. Remembrance of Repasts: An Anthropology of Food and Memory. Oxford: Berg.

Terragni, Laura, Garnweidner, Lisa M., Pettersen, Sverre K. and Mosdø, Annhild. 20I4. "Migration as a turning point in food habits: the early phase of dietary acculturation among women from South Asian, African, and Middle Eastern countries living in Norway." Ecology of Food and Nutrition, 53 (3), 273-29I; doi: 10.1080/03670244.2013.817402 (accessed 9.II.2020).

Tolstokorova, Alissa. V. 20I8. "Food dividends of migration: agents of cross-borderness and cultural continuity." Zhurnal Frontirnykh Issledovaniy, 2, 70-88.

Trapp, Micah. 2016. "You-Will-Kill-Me Beans: Taste and the Politics of Necessity in Humanitarian Aid." Cultural Anthropology 3I (3), 4I2-437. https://journal.culanth.org/index.php/ca/article/view/ ca3I.3.08/38I (accessed 9.II.2020). 
Vallianatos, Helen. and Raine, Kim. 2008. "Consuming food and constructing identities among Arabic and South Asian immigrant women in food." Culture and Society II (3): 355-373.

Williams-Forson, Psyche A. 2006. Building Houses out of Chickens Legs. Black Women, Food and Power. Chapel Hill: The University of North Caroline Press.

\section{AUTHOR'S CONTACT}

Magda Bodzan, PhD student

Institute of Ethnology and Cultural Anthropology, University of Warsaw

e-mail: magdabodzan@student.uw.edu.pl

ORCID: 0000-0002-I239-4284

(c) $\$$ 